Cahiers $d u$ MONDE RUSSE

\section{Cahiers du monde russe}

Russie - Empire russe - Union soviétique et États indépendants

$58 / 1-2 \mid 2017$

1917

\title{
The Russian Revolution in German Historiography after 1945
}

La révolution russe dans l'historiographie allemande après 1945

\section{Matthias Stadelmann}

\section{OpenEdition}

\section{Journals}

Electronic version

URL: http://journals.openedition.org/monderusse/10066

DOI: 10.4000/monderusse. 10066

ISSN: $1777-5388$

\section{Publisher}

Éditions de l'EHESS

\section{Printed version}

Date of publication: 1 January 2017

Number of pages: $57-78$

ISBN: 978-2-7132-2696-0

ISSN: $1252-6576$

\section{Electronic reference}

Matthias Stadelmann, «The Russian Revolution in German Historiography after 1945 », Cahiers du monde russe [Online], 58/1-2 | 2017, Online since 01 January 2019, Connection on 08 January 2020. URL : http://journals.openedition.org/monderusse/10066; DOI : 10.4000/monderusse.10066 


\section{MATTHIAS STADELMANN}

\section{THE RUSSIAN REVOLUTION IN GERMAN HISTORIOGRAPHY AFTER 1945}

Nineteen seventeen ranks among the most described years of Russian history. Irrevocably and in a far-reaching way, the year of the two revolutions saw significant upheavals in the state, economy, culture and society in Russia, and mightily influenced regions soon coming under the territorial and administrative umbrella of the USSR as well as countries outside the Soviet empire. The October Revolution, particularly, was branded as a decisive caesura in modern history. How did historiography in Germany analyse Russia's 1917? This article traces the paths of post-war West German historiography of the Russian revolution and describes the historical preconditions and peculiarities that shaped it. ${ }^{1}$ East-German historiography is excluded because it followed the path of Soviet research on 1917 and was very much engaged in unveiling "bourgeois falsifications". ${ }^{2}$ It had no influence on West German historiography at all.

Was (or is) there something like a "national" German historiography and what meaning could this characterization have as to research on the Russian Revolution? If we define scholarship and research as a process of coming to knowledge and perception by methods and theories and the help of sources, there is no space for any national path towards cognition as long as we consider that we have reached it through scientific means. However, the history of historiography unmasks the notion as illusory, particularly when German traditions of history writing are concerned. The question cannot easily be pushed aside, since there were strong institutional and personal continuities that bridged the caesura of 1945 . Many of the historians who either supported the ideology of National Socialism or actively took part in the politics of extermination before 1945 were brought into service in West German universities. In particular, members of the imperial, "völkisch" and partly racist Ostforschung research organisation never broke up their networks and were eager to support each other under the conditions of the new democratic order. Historians like Theodor

1This article does not claim to completeness. I am greatly indebted to Stefan Plaggenborg for intense discussions, Fabian Wisotzky for valuable organizational help and Ewald Stadelmann for thorough advice in translation.

2Ernst Engelberg, Die deutsche bürgerliche Geschichtsschreibung zur Großen Sozialistischen Oktoberrevolution (Berlin, 1967); Gerd Vogt, "Die Verfälschung der Großen Sozialistischen Oktoberrevolution in der neueren westdeutschen Literatur”, Zeitschrift für Geschichtswissenschaft, 18 (1970): 353-360. 
Schieder, Hermann Aubin, Reinhart Wittram and Werner Markert (just to mention a few important names), who backed the ideology and politics of the Nazi regime, became professors of Eastern European history at West German universities. ${ }^{3}$ Only a minority looked back in a self-critical way and questioned the historians' roles and functions in the years before 1945. In particular, Werner Philipp, a specialist in the Muscovy period, openly addressed problematic chapters of biography, burdened his generation of researchers with the blame of not having resisted to ideological demands, and recommended a critical stance on the historians' participation during the Third Reich. ${ }^{4}$ The majority, however, remained silent and tried to avoid any debate about biographies and careers. They tried to cleanse their work of now compromising beliefs and phrases, but kept certain elements of their Weltanschauung alive, particularly their perception of Bolshevik Russia as a threat to Western civilization (which they, ironically, had helped ruin during the years 1933-1945) especially after Soviet expansion in Central Europe, and their strong anticommunism. This period in West German historiography has been analysed for many years, and there is no need to go into detail here; suffice it to say that Ostforschung historians, because of the mainly "völkisch" character of their approach, hardly worked on the Russian Revolution as a special topic. ${ }^{5}$ For a better general understanding, one should mention here that professorships and chairs at German universities were - and still are-called "for Eastern European History", which ideally means teaching courses covering the entire region and full historical time span. Since 1935, when the historian Otto Hoetzsch was forced to leave the chair of Russian History at Humboldt University in Berlin, Russianists have found themselves among the other historians specialising in Eastern Europe. ${ }^{6}$

3Winfried Schulze, Otto Gerhard Oexle, eds., Deutsche Historiker im Nationalsozialismus (Frankfurt on the Main, 2000); Michael Fahlbusch, Ingo Haar, eds., Handbuch der völkischen Wissenschaften: Personen, Institutionen, Forschungsprogramme, Stiftungen (München, 2008).

4Werner Philipp, "Nationalsozialismus und Ostwissenschaften”, in Universitätstage 1966: Nationalsozialismus und die deutsche Universität (Berlin, 1966), 43-62.

5Fahlbusch, Haar, Handbuch; Gabriele Camphausen, Die wissenschaftliche historische Russlandforschung im Dritten Reich, 1933-1945 (Frankfurt on the Main, 1990); Corinna Unger, “'Objektiv, aber nicht neutral.' Zur Entwicklung der Ostforschung nach 1945”, Osteuropa, 12 (2005): 113-131; Eduard Mühle, “'Ostforschung.' Beobachtungen zu Aufstieg und Niedergang eines geschichtswissenschaftlichen Paradigmas”, Zeitschrift für Ostmitteleuropa-Forschung, 46 (1997): 317-350; from 1952 to 1994 the journal's name was Zeitschrift für Ostforschung, it was edited by Herder Institute in Marburg, the centre of the Ostforscher after 1945. Eduard Mühle, Für Volk und deutschen Osten: Der Historiker Hermann Aubin und die deutsche Ostforschung (Schriften des Bundesarchivs 65) (Düsseldorf, 2005); Esther Abel, Kunstraub - Ostforschung - Hochschulkarriere: Der Osteuropahistoriker Peter Scheibert (Paderborn, 2016).

6Erwin Oberländer, ed., Geschichte Osteuropas: Zur Entwicklung einer historischen Disziplin in Deutschland, Österreich und der Schweiz, 1945-1990(Stuttgart, 1992). 
It is important, however, to keep in mind that German historiography of Eastern Europe in general and Russia in particular, needed several years to get rid of the thinking in terms of civilizational threat and anticommunism that easily fit into Cold War ideology. Therefore, these approaches were not problematic for many years and rather helped integrate historians with more or less compromising careers before 1945 into the academic world, where the early West German society's self-understanding facing the communist German Democratic Republic as immediate neighbour prevailed. However, the fact that historiography in Germany was kept apart from the theoretical and methodological debates going on in other parts of the world had much greater effects. One of the central issues in German historiography during the 1950s and 1960s was to catch up with methods and theoretical frameworks. ${ }^{7}$

\section{Interim: the Russian revolution in German historiography between 1945 and 1968}

The 1945-1968 period may be regarded as an interim. Historians tried to come to terms with the Bolsheviks without falling back on Nazi research paradigms on the one hand and without new and alternative research paradigms on the other. It ended with the publication in 1968 of Dietrich Geyer's Die Russische Revolution, to be discussed later.

The problem of the interim literature is best exemplified by Georg von Rauch's History of Bolshevik Russia, published in $1955 .{ }^{8}$ In the words of Hans von Rimscha, who, like von Rauch, was of German-Baltic origin, the book "had to be written, although practically it could not". Von Rimscha referred to the discrepancy between the attempt to historicise Bolshevik Russia and the problematic source base in 1955, ten years after the end of the Second World War and at the height of the Cold War. Von Rauch shared the general problem of Western historians of Russia - he had no access to the necessary source material enabling him "to really write a history of the country". Given the lack of documents, numerous conjectures replaced material-based arguments. It is not our aim to discuss whether von Rauch's book fulfilled its promise to be a "history of Bolshevik Russia". Von Rimscha benevolently called it "a reliable, useful and certainly widely welcome guideline to the Kremlin's policy of that time". 9

7Ernst Schulin, ed., Deutsche Geschichtswissenschaft nach dem Zweiten Weltkrieg (1945-1965) (München, 1989).

8Georg von Rauch, Geschichte des bolschewistischen Russland (Wiesbaden, 1955).

9H[ans] v. Rimscha, "Review of Georg von Rauch, Geschichte des bolschewistischen Rußland, Wiesbaden 1955”, Historische Zeitschrift, 182 (1956): 673-676, quotations 673f., 676. 
For our present purpose, it is important to note von Rauch's strong emphasis on official politics. Social classes or groups and economic developments and problems are mentioned only incidentally, if at all. Thus, von Rauch fit into the prevailing historiographic paradigms of his time: in the 1950s, history was mainly considered as the history of politics, political actors, political institutions and political decisions. These decisions were prepared and taken by individuals (no women to be found), so that historic change, generally speaking, was mainly linked to statesmen or, as concerns 1917, revolutionaries, their actions and their impacts. As a consequence, von Rauch considered that there were two extremist directions that divided Russia: on one side, the socialist parties aiming at a system change, on the other, nationalist right-wing circles; since the assassination of Prime Minister Stolypin in 1911, the latter had exerted greater and greater influence on Tsar Nicholas II; ideas of "aggressive foreign policy" dragged the Russian Empire into the war and to its eventual collapse.

For von Rauch, a conceivable perspective beyond violent (self-) destruction could have been provided by the "forces of the centre", which "would have steered the State out of the confusions of internal misery and external temptations in an evolutionary way"-but these anyway not strongly formed forces of the centre were infected and finally disintegrated by Pan-Slavic and Great-Russian chauvinistic nationalism. ${ }^{10}$ In this way, Tsarist Russia was by no means doomed to an inevitable fall, as von Rauch strongly emphasized elsewhere: "The last 50 years of the Tsarist Empire were not marked by decline, but by rapid evolutionary development [...]." Only the reckless entrance into the war in 1914 drove Russia into destruction by provoking crises which the country could not cope with under the impact of greatest tensions. ${ }^{11}$

People primarily affected by the crisis of the autocracy did not play a role in von Rauch's argumentation, typically enough he speaks of "Marxism", "socialism" and of Lenin, but hardly about workers, production, and economic and social problems. Demonstrations in the streets of Petrograd look marginal in comparison to the heroic deeds of the members of the provisional government. For von Rauch, the revolution showed two strongly opposed

10Von Rauch, Geschichte des bolschewistischen Russland, 50.

11 Georg von Rauch, "Betrachtungen zur Frage des Untergangs der russischen Monarchie”, in Hellmuth Rößler, ed., Weltwende 1917: Monarchie, Weltrevolution, Demokratie (Göttingen, 1965), 48-64, quotation p. 49. Here he further explains: "There is a wide range from the liberation of the peasants with all its deficiencies to Stolypin's agrarian reform with 7 million families on heritable farms; from Alexander's not realized constitution with its advisory people assembly to the state duma with its respectable legislative and polemic achievement which gives even to cursory readers of the minutes of the sessions an impression of the level of debates; from the rural illiteracy of the $19^{\text {th }}$ century to the progress of the school system on the eve of war which belongs to the overall picture of a heyday of cultural life; from the economic backwardness of the 1870s to the level of industrialization in 1913, when Russia in textile production ranked second in world economy, and fifth in total production $[\ldots] . "$ 
aspects, on the one hand the insubordinate, illegitimate, murdering and undutiful side, and the legitimized by (the last) elections and responsibility-bearing one on the other. It seems as if the Baltic-German von Rauch, who was born in Pleskau/Pskov in 1904, indulged in wishful thinking about a non-Bolshevik future in Russia instead of analysing the given past. Nevertheless, this perspective made him clearly see the usurpation of power by the Bolsheviks in October. ${ }^{12}$

Von Rauch's one-sided focus on politics and leadership and positivist approach struck critical readers. For example Jesse Clarkson in the American Historical Review in 1957 criticized not only the "essentially unanalytical narrative of events", but also the "almost total neglect of economic factors". ${ }^{3}$ Von Rauch reduced history down to the personalities of Aleksandr Kerenskii and Vladimir Lenin, the former as a possible alternative for the future leadership of Russia, the latter as a demonic seducer and destroyer, who since April 1917 had "each time held his listeners more and more spellbound"; in spite of "a jerky and unmusical" manner of speaking and thanks to "primitive demagogic simplifications", Lenin was said to be able to unfold "suggestive power of persuasion" among the workers:

They were carried along by the enormous willpower of this unusual man; the destroying fire of his rhetoric enflamed the masses agitated by war and revolt like tinder [...]. It was the anarchic instincts of the masses that Lenin knew how to stir up.

In von Rauch's presentation, the function of these masses in 1917 was limited to being "fanaticized" by Lenin and serving as "tools of the irrepressible desire for power". ${ }^{14}$

A little more differentiated was von Rauch's assessment in his booklet Lenin: The Foundation of the Soviet System, published in 1957 ( $2^{\text {nd }}$ edition 1958) in the series "Persönlichkeit und Geschichte [Personality and History]". Referring to Lev Trotskii, he described the October Revolution as "a combination of an organized, carefully prepared conspiracy by a minority and a general, but unclear and therefore easily controllable public current". Von Rauch recognized that "the development from May to October had produced

12Von Rauch, Geschichte des bolschewistischen Russland, 91.

13Jesse D. Clarkson, "Review of Georg von Rauch, A History of Soviet Russia, New York, 1957", The American Historical Review, 63 (1957): 127-128, quotations p. 128. See also Richard Pipes, "Review of Georg von Rauch, A History of Soviet Russia, New York, 1957”, The Slavic and East European Journal, 3 (1959): $85-86$. 
many sympathies for the Bolsheviks within broader circles". Yet, in this booklet also, the personal-political aspect in the shape of Lenin's character stands clearly in the foreground. ${ }^{15}$

This rather detailed presentation of von Rauch's book aims to show the ways of historiography in the interim period and make sense of the critique by Geyer. There were other books similar to von Rauch's, for example Günter Stökl's Russian History. ${ }^{16}$ Stökl taught at the University of Cologne and specialized in the history of Old Russia. In his book, he also emphasised political developments but clearly regarded the actions of Duma members with much more restraint than von Rauch. It seems as if the Austrian Stökl had a sharper eye in seeing through the political problems of the Russian liberals than the Baltic-German von Rauch, who clearly identified with liberal politics after the fall of the monarchy. Although Stökl looks considerably more distinctly at the dualism between the provisional government and Petrograd Soviet, he agrees with von Rauch about the fate of the February Revolution: the victory of the Revolution was to come as soon as the Petrograd garrison mutinied and made common cause with the workers. He also principally agreed with von Rauch in the assessment of the October events: "It was not the masses of the people [that] were lifted", but only "the party of the Russian communists under Lenin's leadership". ${ }^{17}$

To conclude this chapter, one should briefly mention Manfred Hellmann's widely used source collection The Russian Revolution 1917, part of the "Dtv-dokumente" series. Hellmann taught at Münster University and was a specialist in the medieval history of Eastern Europe. His approach was completely marked by the political-personal perspective: the February Revolution, the provisional government and the Bolshevik coup were the milestones of this source compilation. The empire's collapse was mainly caused by the deficiencies of the imperial couple Nicholas and Alexandra, the intrigues of the court camarilla, and government malfunction, mostly due to Prime Minister Goremykin. We learn: statesmen, Lenin and Trotskii included, pushed history forward. ${ }^{18}$

Positively said, German historiography of 1917 was looking to the future and tried to figure out how the Russian Revolution could be understood in a way that was not determined by cultural hierarchy, "völkisch" superiority and racial inferiority. That made politics, personalities and power come to the foreground. Negatively said, German historians of 1917

15Georg von Rauch, Lenin: Die Grundlegung des Sowjetsystems (Göttingen 21958), 64.

16Günter Stökl, Russische Geschichte: Von den Anfängen bis zur Gegenwart (Stuttgart, 1962).

17Stök1, Russische Geschichte, 650.

18Manfred Hellmann, ed., Die russische Revolution 1917: Von der Abdankung des Zaren bis zum Staatsstreich der Bolschewiki (München, 1964), introduction by the editor (7-40). 
had dramatically lost contact with historiography outside Germany, they were not at all able to come to terms with a complex phenomenon like the Russian Revolution because they had no idea of how to study a revolution that went beyond their categorical understanding of history; they neither had the intellectual sensorium nor the methodological instruments for it. One had to wait until the end of the 1960s, when the social approach opened the doors for new perceptions. This approach was mostly adopted by the younger generation of historians, who had no scholarly roots in Nazi Germany. However, ironically or not, historians who were very much sympathetic with Nazi ideology and more or less openly anti-Semitic had paved the way for this turn. Werner Conze became one of the protagonists of social history in the German Federal Republic. There was also oscillating Peter Scheibert (see below), who built up a group of young historians at Marburg University that came to publish books on the social history of Soviet Russia. Some historians burdened with active participation in the National Socialist regime and politics very quickly adapted to varieties of social history.

\section{New beginnings in the late 1960s}

If 1917 was a caesura in Russian history, the 1970s were a turning point in German historiography of 1917. The new orientation was partly generational, partly a question of methodological and theoretical information. It took more than 20 years since 1945 and the coming of the $50^{\text {th }}$ anniversary of Russia's 1917 until a book was published that may be regarded as a new beginning in German historiography on 1917. Dietrich Geyer's The Russian Revolution: Historical Problems and Perspectives ${ }^{19}$ was the starting point for descriptions and interpretations of 1917 in the following years, i.e., prudent and thoughtful, methodologically well informed, theoretically safely grounded studies, but with a remarkable lack of archival sources. Or, to bring it to the point, intelligent interpretations that had to rely on sources provided by Soviet colleagues or could be found in Western, mostly American, institutions. As the book's title indicates, Geyer's aim was not a coherent empirical description of the revolutionary events, but an introduction to "modern historical research" 20 that based scholarly expertise on methods and particularly on theoretical categories that helped make the Russian Revolution part of history rather than of political intentions and civilizational problems. His book tried to leave behind the inappropriate descriptions by German historians before him and schematic and distorting Marxist interpretations from the Soviet side. He criticized former historiography with rhetorical pungency, giving a description of its errors and deficiencies:

19Dietrich Geyer, Die Russische Revolution: Historische Probleme und Perspektiven (Göttingen ${ }^{4}$, 1977; first edition Stuttgart, etc., 1968).

20Geyer, Die Russische Revolution, 8. 
Meanwhile there are indicators that historical research is getting realigned, that historians try to consider causes and developments leading to the revolution in a new and more sober way without temptations to regard problems ideologically instead of uncovering them. Old positions are given up, old formulations verified. What promises new insights and scholarly respect does not run after scandal and secret-service stories which accompanied the Russian Revolution as well; it does not limit itself to bio-psychological analyses as was shown recently by exalted endeavours to uncover the secret roots of revolution in Lenin's sexual life and the frustration of the revolutionaries. ${ }^{21}$

A professor of Eastern European History in Tübingen, Geyer gave a lecture series in 1967 on the Russian Revolution that became the basis of his book. Five out of the book's eleven chapters deal with the preconditions of the Revolution, i.e., the structures and processes of the Russian Empire and its end. Geyer was sceptical about the Tsarist Empire's successful adaptation to the growing problems of the early $20^{\text {th }}$ century. Thus, he abandoned the view that a partially reformed system, which à la longue had good perspectives to develop, was drawn into the abyss by the personal failure of the elite at court in a time of extreme tensions during the war. The option of a Russian constitutional monarchy having had a chance if the First World War had not taken place was no question for him but rather why "the old regime, which had lost its broad social basis long ago, continued to exist and was able to control revolutionary danger over the decades preceding the war". ${ }^{22}$ Concomitantly, he rejected "that rigid historical determinism which was blasted to us from the east: revolution as a mere necessity, as the quintessence of the historical process". ${ }^{23}$ In particular, he focused on socio-economic problems, which today does not seem noteworthy at all, but at the time, this approach was novel in German historiography of the Russian Revolution. The agrarian question, misery in the countryside, which after Stolypin's reforms was at best in a stage of change, but had not entered a phase of general prosperity, and the workers' question were the decisive challenges for Russia's autocracy. Above all, the workers' discontent, backed by the

21Ibid., 17 .

22Ibid, 32. Also the Hamburg historian Klaus Detlev Grothusen emphasized in a lecture series in Münster, published in 1969, that "the overthrow of the tsarist regime [...] was the result of internal crises that had been smouldering for decades". Klaus Detlev Grothusen, "Von der Februarrevolution zur Oktoberrevolution: Die Zeit der Provisorischen Regierung", Die Russischen Revolutionen von 1917. Eine Vorlesungsreihe (Wiesbaden [Schriften der Arbeitsgemeinschaft für Osteuropaforschung der Universität Münster], 1969), 3-17, quotation p. 4.

23Geyer, Die Russische Revolution, the following quotations always according to the fourth edition, unchanged in the main text, 17 . 
political intelligentsia, along with grown proletarian organizational capability strongly undermined the authority of the autocratic state, even though the industrial proletariat carried less weight in quantity than the peasant majority.

While explicitly turning against the reduction "of the history of revolution to a personal issue", ${ }^{24}$ thus rejecting the interpretation of the revolution's pre-history as a personal failure of the last tsar, Geyer considered social problems, the gap between state and society, the destructive powers of war and the breakdown of liberal-bourgeois alternatives in summer 1917 as the conditions for the future Bolshevik victory. However desolate and desperate the state of the governmental rump may be described, still the Bolshevik takeover in October was "the result of a violent action aiming for the downfall of the provisional government". ${ }^{25}$ But the military success of the October coup was due to the political victory the Bolsheviks had gained before when they won the soviets as organs of revolutionary democracy. In a way, the coup was legitimized by Petrograd democracy.

In the same provocative way, Geyer confronted his elder colleagues with the notion that the October revolutionaries stayed in power not only through brutal terror, but because the "secret of their success" was above all skilful politics with "plebiscitary quality". The Bolsheviks implemented what the people wanted and "since February 1917, in their manifestos and programs, the parties of soviet-based democracy" only "had paraded around". ${ }^{26}$

Geyer also emphasized the Bolsheviks' practical lack of planning after coming to power: "The Bolshevik party was only to a limited extent the directing force." They let themselves be drifted by the interests of the lower classes, the satisfaction of whose wishes they had inscribed on their banners. In addition, their own experience and skills were poorly developed. Thus, the tolerance for "anarchic mass activity" turned out to be essential for the consolidation of Bolshevik power. Yet, the party soon began to rally and concentrate its forces into substantial power structures. This was accompanied by a "shift from making politics based on soviet democracy to politics decided on by the Bolshevik party", in other words: the soviets were confined to administrative and later acclamatory functions. The brief democratization by soviets was rapidly transformed into a bureaucratic system of rule which later became Stalin's educational dictatorship. ${ }^{27}$ Geyer regarded the Bolsheviks' rigid policy

24Ibid., 64.

25Ibid., 93 .

26Ibid., 107-117, quotation, $116 f$.

27Ibid., 118-129, quotations, $120 \mathrm{ff}$. 
as the only way to maintain power under the specific conditions of post-revolutionary months; otherwise, they would have lost power right away to-internal or external-opponents. ${ }^{28}$

In his conclusion, Geyer made a very broad and - if we look at the $100^{\text {th }}$ anniversary of the year 1917-still relevant statement presenting the revolution in a global perspective:

Those who do not want to give an account of the events, but to find principles and judgements, will have to ask for the meanings of this revolution for today's world history.

At this stage of discussion, Geyer finally opened his methodological and theoretical canteen. Looking for "historical processes and structures which, in essence, have a long duration", he made clear that he was talking of a "gradual evolution of universal modernization". His approach limited the relevance of events in favour of the overriding issue, "industrialization and modernization of a backward, retarded agricultural country", which for him was an "absolute priority" for Russian politics between 1890 and 1930. One may conclude that his structural-historical view declares the tsarist ministers Witte and Stolypin and the "Stalinist planning commissars" to share the same objective, achieving modernization of Russia and having the country meet the standards of the time. The Russian October Revolution thus was part of a comprehensive large-scale "modern world revolution" - and as such, 1917 displays potential as a turning point as a "new category of revolution [...]: a way of changing the world, created at first in Russia, according to designs for the future programmed by elitist small groups". ${ }^{29}$

Seen from today's perspective, the novelty of this approach to the Russian Revolution is somewhat relative, since Geyer was not at all the only one who was an adherent of Historische Sozialwissenschaft [history as a social science], the paradigm that started to dominate German historiography in general in the $1960 \mathrm{~s}^{30}$ It is widely known by its "Bielefeld school" label, the German history experts Hans-Ulrich Wehler and Jürgen Kocka

28Ibid., 124f.

29Ibid., 130-141, quotations, 130, 135ff., 140. The process of relativisation of the legend about the Bolshevik clique meticulously planning everything was started by Walter Pietsch in 1969, who underlined pragmatism, improvisation and chaos in the establishment of Bolshevik power from 1917 on. See his study Revolution und Staat: Institutionen als Träger der Macht in Sowjetrussland 1917-1922, (Cologne [Abhandlungen des Bundesinstituts für Ostwissenschaftliche und Internationale Studien 20], 1969).

30Hans-Ulrich Wehler, ed., Geschichte und Soziologie (Cologne, 1972); Hans-Ulrich Wehler, ed., Geschichte und Ökonomie (Cologne, 1973); Hans-Ulrich Wehler, Historische Sozialwissenschaft und Geschichtsschreibung: Studien zu Aufgaben und Traditionen deutscher Geschichtswissenschaft (Göttingen, 1980). 
being its main protagonists; the newly founded (1975) journal Geschichte und Gesellschaft [History and Society] was its mouthpiece. It focused on economy, interests, social classes and their roles, on society, institutions and general structures, and considered any notion that "great men make history", any personalised history and ideology as a force of development and historical action as elements of an obsolete historiography. Sociology became the mother of historiography, Max Weber the theoretical sun in the sky of structuralism, and modernization theory the analytical basis of interpretation. ${ }^{31}$ Surely this kind of depersonalized and anonymous, de-ideologized and spiritless (not to be understood as uninspired) historiography regarding structures as historical actors allowing to strictly objectify historical processes was a reaction to the recent past in German historiography. As to research strategies, the social science turn was absolutely necessary to overcome the remnants of Ostforschung and all sorts of eccentric, often synonymously anti-communist "Sovietology" that blossomed during the Cold War era. It was also necessary to catch up with historiography outside Germany. The late 1950s and 1960s became years of intense debates over how to write history. One must place Geyer's book on the Russian Revolution within this context to understand its relevance and meaning.

Severe critique of Geyer's comprehensive description of Bolshevik power came as no surprise. Decades later, Heinz Brahm, then scientific director of the Bundesinstitut für ostwissenschaftliche und internationale Studien (Federal Institute for Eastern [i.e., Eastern Europe, Caucasus, Middle Asia and China - M.S.] and international studies) in Cologne, still called him "Lenin's determined body guard", a reproach that Geyer rejected and that was a late echo of an outlived historiography. ${ }^{32}$ It is interesting to know that the Institute was founded in 1961 under the name Institut zur Erforschung des Marxismus-Leninismus [Institute for the study of Marxism-Leninism]; it stood under the administrative auspices of the Ministry of Interior and was designed as a think-tank to advise the federal government of the German Federal Republic. Yet it is beyond doubt that Geyer's interpretation of the Russian Revolution also corresponded to the political climate in West Germany in the late 1960s, particularly in universities. In an interview in 2005, Geyer himself commented on his book:

It was the spirit of the time that stimulated me. [...] What I found

particularly exciting and impressive was the global worldwide

framework of revolutionary thinking, the fact that proletarian

31Hans-Ulrich Wehler, Modernisierungstheorie und Geschichte (Göttingen, 1975).

32Cf. Susanne Neumann, Leninbilder: Lenin in der westdeutschen Geschichtswissenschaft in den 1960er bis 1980er Jahren (Hamburg, 2006), 96ff. and 171ff.; Heinz Brahm, "Schreibtischtäter Lenin”, Osteuropa, 50 (2000): 1115-1122, quotation, 1117. 
revolution, agrarian revolution, anticolonial and anti-imperialistic revolution were merged by Lenin.

It was not only Geyer who was impressed by the revolutionary mood of the time, but also the majority of students. For this "fucking liberal" [Scheißliberaler], in the jargon of that rebellious time, the leftist spirit of German universities offered a proper embedding for his scepticism about the primitive and superficial anti-communism of an ideologized historiography. ${ }^{33}$ While he would have been politically and academically hanged in the mid$1950 \mathrm{~s}$, as the chapter on the interim period shows, the students' movement in the late 1960s, with its antifascist implications, strongly supported his new interpretations. It should be noted that the Historische Sozialwissenschaft approach was continued by historians of the Tübingen institute such as Manfred Hildermeier, Dietrich Beyrau, and Bernd Bonwetsch, whose studies on the Russian revolution will be reviewed below.

\section{Pluralism in social history studies}

During the 1970s, many Russianists dealing with the modern history of the Russian Empire focused either on the pre- or post-revolutionary period. Some focused on long-term causes leading to 1917 and studied intensely but without historical teleology the ambivalent modernisation of tsarist Russia and its contradictory results, others were interested in what followed after October without historical teleology leading to Stalinism. The emerging pluralism of studies methodologically based on the social history paradigm concentrated at certain universities where professors were able to build up groups of young researcherstoday one would call them graduate schools - who studied within the "research programme" of that particular department.

The above mentioned Peter Scheibert, who "in his former life" was a member of the Waffen-SS and participated in the art and archival document "protection" campaigns, i.e., robbery and elimination of the culture of "inferior peoples" in Eastern Europe during the Second World War, ${ }^{34}$ and who unsuccessfully attempted to write a sort of three-volume intellectual history of the revolution from Bakunin to Lenin, of which only one was published, ${ }^{35}$ gathered young historians around him who studied the first years after the revolution. Located at Marburg University, the group left "Sovietology" behind and opened

33Cf. Susanne Neumann's interview in 2005: "Neumann, Leninbilder", 171-184. Geyer's quotations on p. 174, 176. The expression Scheißliberaler was an ironic self-characterization by Geyer in 2005 seen from the perspective of his opponents.

34Abel, Kunstraub.

35Peter Scheibert, Von Bakunin zu Lenin: Geschichte der russischen revolutionären Ideologien 1840-1895 (Leiden, 1956). 
new fields of research by looking at the social developments, economic change and institutional patterns of the new Soviet state. Such a research programme had a certain intellectual precondition. It accepted the Bolshevik takeover and the communists' power not in terms of ideology and brutal violence, but as a fact that had to be studied in all its facets. Until the middle of the 1970's, several dissertations opened insights into the inner history of Soviet state and society. Uwe Brügmann studied the role of trade-unions and the hot debate about the theory of "étatisation", ${ }^{36}$ Heiko Haumann, the beginning of economic planning, electrification and the GOELRO utopia, ${ }^{37}$ Gert Meyer, the turn from war communism to NEP and the relationship between town and countryside, ${ }^{38}$ and Richard Lorenz, the socio-economic developments between the revolution and Stalin's era (discussed below). ${ }^{39}$ Peter Scheibert, who eagerly tried to hide his career before 1945 from public discussion, certainly was not amused when he learned that all these young historians became leftists.

This group was not one of its kind. Like mushrooms after a warm rain, during the 1970s dissertations dealt with issues related to the revolution and more particularly its consequences. New chairs in Eastern European History were created, and more or less young scholars had a chance to build up a new Soviet history. In 1969, Walter Pietsch published his Revolution and State, which turned Lenin's State and Revolution upside down; the book may be regarded as the then fundamental study of organisational and institutional developments during and after the revolution. ${ }^{40} \mathrm{He}$ wrote his dissertation at Freiburg University, where Gottfried Schramm, who had been Scheibert's assistant in Marburg, gathered young historians around him in order to work on the third volume of the Handbook of Russian History, which covered the 1856-1945 period. ${ }^{41}$ Heiko Haumann found a fruitful asylum in Freiburg after Scheibert had severely tried to control his teaching and further studies. This incident (and the one concerning Richard Lorenz to be discussed below) showed that obsolete ideological

36Uwe Brügmann, Die russischen Gewerkschaften in Revolution und Bürgerkrieg 1917-1919 (Frankfurt on the Main, 1972).

37Heiko Haumann, Beginn der Planwirtschaft: Elektrifizierung, Wirtschaftsplanung und gesellschaftliche Entwicklung Sowjetrußlands 1917-1921 (Düsseldorf, 1974).

38Gert Meyer, Studien zur sozialökonomischen Entwicklung Sowjetrußlands, 1921-1923: Die Beziehungen zwischen Stadt und Land zu Beginn der Neuen Ökonomischen Politik (Cologne, 1974).

39Richard Lorenz, Sozialgeschichte der Sowjetunion I: 1917-1945 (Frankfurt on the Main, 1976), 12-13; a planned second volume never appeared.

40Pietsch, Revolution und Staat.

41Gottfried Schramm, ed., Handbuch der Geschichte Rußlands (Stuttgart, 1983/1992). Vols. 3,1 and 3,2. 1856-1945: Von den autokratischen Reformen zum Sowjetstaat. 
questions still were "in the air" and could have serious effects on young scholars if their research displeased their professors. In the tolerant atmosphere of Freiburg University, Haumann wrote his Capitalism in Russia during the First World War, in which he tried to determine the state of development of capitalism, its structural patterns and the socio-political roles of entrepreneurs and their organisations during the final stage of autocracy. ${ }^{42}$ Of course, this publication was an answer to Lenin's views on capitalism.

The blossoming of Soviet studies at several universities revealed the leading role of social history. These studies considerably widened the empirical knowledge of social and economic developments in Soviet Russia and drove political history to the background. Politics mattered in relationship with economics and social developments in Helga Schuler-Jung's Economy and Politics in Soviet Russia, 1920-1924, in which she focused on the debates on economic alternatives and their impacts on political and personal changes in the Bolshevik party and state organs. ${ }^{43}$ The publications of the 1970s and early 1980s reflected the lively pluralism of social history studies. One should not forget to mention that some of the dissertations of that period were fundamental and have remained so to this day, as for example Hans-Henning Schröder's social history of the Bolshevik Party. ${ }^{44}$ Schröder's detailed description of membership, social origin, education, inner-party social mobility (vydvizhentsy) and in particular the relationship between General Secretary Stalin and incomers was path-breaking for the understanding of Stalin's way to power.

Richard Lorenz deserves short special consideration. He studied philosophy in Leipzig and became the assistant of the philosopher Ernst Bloch. After he left the German Democratic Republic in 1957, he studied sociology and psychology and started working at the famous Institut für Sozialforschung in Frankfurt on the Main. Under the supervision of Scheibert, he wrote his doctoral dissertation on "The beginnings of Bolshevik industrial policy". In Marburg, he started working on his Habilitation. The book was finally published in 1976, but the qualification to get a professorship was denied by Scheibert because of "serious concerns" as to the quality of the study he had strongly supported before because of its innovative character. One can hardly oversee the political aspects of the conflict, since Marburg

42Heiko Haumann, Kapitalismus im zaristischen Staat 1906-1917: Organisationsformen, Machtverhältnisse und Leistungsbilanz im Industrialisierungsprozess (Königstein, 1980).

43Helga Schuler-Jung, Ökonomie und Politik in Sowjetrußland 1920-1924: Zum Prozeß der Willensbildung in der KPR(B) in den ersten Jahren der Neuen Ökonomischen Politik (Marburg, 1978).

44Hans-Henning Schröder, Arbeiterschaft, Wirtschaftsführung und Parteibürokratie während der Neuen Ökonomischen Politik: Eine Sozialgeschichte der bolschewistischen Partei 1920-1928 (Wiesbaden, 1982); on bureaucratisation see Ursula Nienhaus, Revolution und Bürokratie: Staatsverwaltung und Staatskontrolle in Sowjetrußland 1917-1924 (Frankfurt on the Main, 1980). 
University at that time was called "red Marburg", and Scheibert certainly did not belong to this wing while Lorenz did. ${ }^{45}$

In his Social History of the Soviet Union, Lorenz analysed 1917 exclusively from a socio-economic point of view:

The $[\ldots]$ presentation focuses on the development of production conditions, which at the same time are connected with relations of power and dependence. Political institutions are dealt with only in so far as it is necessary for the understanding of socioeconomic processes.

He decidedly opposed the "traditional historiography of Russia, interested mainly in the expansion of power", but also "recent theories of development" in terms of a "global process of modernization". No doubt, Lorenz was strongly influenced by Marxism. For him, the fate of socialist Russia lay in the relationship between peasants and workers. ${ }^{46}$

The conception and vocabulary of the text disclose a Marxist understanding of history, with the conviction of no alternative to Bolshevik revolution. The study often appears as a variant of Soviet publications ideologically brought into line, yet with a certain educated mildness and professorial serenity, without overwhelming exultation about the Bolsheviks' liberation of mankind, but with an unshaken conviction of its necessity. The revolutions of 1905-1907, February and October 1917 constituted "a consistent process, which ran out from the same social powers, mainly the proletariat and the peasantry, and from the start was characterised by outlines of anti-capitalism". The Bolsheviks placed themselves at the top of the revolutionary mass movement; they came to power because they were the only ones who were able to combine the features of democracy with socialist goals. ${ }^{47}$ The bourgeoisie and the liberals in general played no historically significant role. To sum it up: the Bolsheviks became the only socio-political alternative during 1917; Lenin opened the eyes of the people on the errors and deficiencies of the provisional government and on October $25^{\text {th }}$, the congress of soviets "decided the transformation of Russia into a Soviet Republic". ${ }^{48}$ Lorenz brought a new quality to West-German historiography of the Russian Revolution, and this in two respects: on the one hand, with a consistent Marxist-inspired social and economic approach focusing on just a few historical figures and conceiving political groups as very static entities,

45Abel, Kunstraub, 208-221. Lorenz eventually became a professor at Kassel University.

46Lorenz, Sozialgeschichte, 12-13.

47Ibid., 47.

48Ibid., 68 ff., quotations, 70, 72f., 76. 
and based on a broad economic material basis; on the other hand, with a learned, but undisguised retelling of the Bolshevik narrative, though in a West European structural-historical design. ${ }^{49}$

Other historians focused on the pre-revolutionary era and rarely on the revolutionary process itself. In 1983, Gottfried Schramm summed up the state of research in the third volume of the monumental Handbook of Russian History. ${ }^{50}$ In contrast to the tendency of social and structural historiography, the Freiburg historian considered that the Russian Empire was by no means doomed to a downfall since the cohesion of the liberal society, self-administration and will to reform had not fully blown up. Notwithstanding all the pressures, Russia did not collapse during the war; additionally, the military situation was not as bad as it was willingly circulated to be. It was fatal for the monarchy that during the February turmoil no reliable army units were left in Petrograd. Schramm suggested that a liberal alternative would have been possible if enormous errors had not been made by the rulers out of unrealistic isolation such as the refusal to make prompt and adequate concessions and indecisiveness with regards to the capital.

Such an interpretation was disputable, but it was undeniably based on a fine study of the literature and a broad knowledge of sources. Other publications focusing on prerevolutionary history were not as judicious, e.g. Bernd Bonwetsch's History of the Russian Revolution, qualified by its subtitle as a "social history from the peasant emancipation to the October coup". The author, a specialist in the history of Russia during the world wars, described pre-revolutionary developments rather schematically, and he had quite a special sense of proportion when he concluded:

It is true; the estates of the nobility were eliminated, so were to a large extent those of the bourgeoisie. But as concerns the situation and disposition of the big mass of the population in the countryside, in the factories or in the city which emptied itself for a couple of years, in principle only Stalin's revolution from above brought real changes. In

\footnotetext{
49Almost 30 years after the publication of his book, Lorenz reacted in an oddly indifferent way when asked by Susanne Neumann if he had seen himself as a Marxist. Lorenz replied evasively: "If you ask me, were you left-wing? then I would say, yes I was left-wing. But a Marxist? That is a difficult term in science and above all in historiography." To the argument of the interviewer that Lorenz after all had operated in his Social History of the Soviet Union with Marxist tools, his laconic answer was: "But everyone did that. Is that Marxist?" Lorenz should have read his own book once more, and then he would have known that he not only was Marxist, but Bolshevik, too. But maybe in 2005 it simply was no longer fashionable to be a Marxist. Cf. "Neumann, Leninbilder", 151-162, quotations, 157.

50Gottfried Schramm, "Interpretationen und Kontroversen", in Schramm, ed., Handbuch der Geschichte Rußlands, Vol. 3,1: Von den autokratischen Reformen zum Sowjetstaat (Stuttgart 1983), 607-612.
} 
the perspective of social history, top and bottom remained to a large extent as they were before the revolution.

As far as politics are concerned, however, the October Revolution meant the "greatest rupture in Russian history". 51

The year 1917 got a little out of sight, but in 1989 Manfred Hildermeier started a large-scale synthesis - in terms of the time frame of the Russian Revolution, from 1905 to 1921, and his use of various explanatory methods. Hildermeier was inspired by the approach of structural history especially for the year 1917. Yet he also stands in the tradition of Geyer insofar as he belongs to those social historians who neither followed a "natural" materialistic determinism nor entirely disregarded personal factors. Notwithstanding the imprint of structural history on him, Hildermeier retained independent openness for multiple perspectives. In this way, the Revolution to him was a long-term, structurally justified and in its concreteness a spontaneously uprising issue as well. Two requirements "prepared the ground for the secular upheaval of 1917 [...]: the crisis of the old regime and the world war". 52

Hildermeier identified four essential crisis areas in the Russian Empire at the beginning of the $20^{\text {th }}$ century:

1. the structural crisis of the agricultural sector, where the liberation of the peasants in 1861 created more problems than it solved;

2. the worker question, with the emergence of a rapidly growing, easily "politcizable" new underclass in densely populated cities;

3. the intelligentsia forced into opposition to the state;

4. the crisis of state power, where Hildermeier wants to position himself in a differentiating way between two historiographic poles-confidence in reformability and the inevitability of the breakdown.

51Bernd Bonwetsch, Die Russische Revolution 1917: Eine Sozialgeschichte von der Bauernbefreiung 1861 bis zum Oktoberumsturz (Darmstadt, 1991), $218 \mathrm{f}$. 
Against the background of these crisis areas, the First World War led to the overburdening of Russian autocracy which, "isolated by petrification and political blindness" in the end was unable to summon defenders. ${ }^{53}$

For Hildermeier, the military was decisive for the success of the revolution in two respects. Firstly, he points to the massive desertion of Petrograd soldiers, which "stroke the fatal blow to the old regime". The survival of the revolution during the first turbulent days and even hours was above all guaranteed by the Russian military leadership. "The arrangement between the army leadership and the Duma - and this has been too little recognized so farwas decisive for the triumph [...]." The Revolution could still be stopped, but the military was less interested in a blood bath in the capital than in law and order in the rest of the country. "The general staff was ready to sacrifice the old regime for the overall aim of maintaining the national defence capability and to make arrangements with the Duma." ${ }^{54}$

Although the structural deficits that caused the collapse of the system when it came under pressure are at the centre of explanations, in Hildermeier's description of the developments of 1917, basically structural historical principles remain compatible with political and personal historical approaches. It is the interaction between structures and action, between Russia's massive problems in 1917 and political mistakes that left the democratic government of February no chance at all. ${ }^{55}$ Similar observations can be made about October: "Power was lying on the street and the February Government watched spellbound as the Bolsheviks picked it up, before everyone's eyes." Of course, a structural-historical explanation of the October Revolution cannot boil down to "mere seduction by a fanatic intelligentsia". Yet Hildermeier has no problem accepting the "immense importance of Lenin's personality". Later, he also included Trotskii in his perspective and summed up the essential elements of his interpretation of 1917 in one sentence: "Without understating external pressures, structural problems and the provisional government's serious mistakes

53Ibid., 146.

54Ibid., 133ff., quotations, 205, 135f., 147, 145.

55On the other hand, Hans-Joachim Torke, until his untimely death in 2000 a professor of East European History at the Freie Universität Berlin and primarily a specialist in the Romanov Empire, wanted to rehabilitate the February government by, firstly, underlining the importance of the February Revolution, which would not have been possible without the liberals. In his point of view, the events of February had more significance than the seemingly more spectacular October Revolution because the end of 1000 years of monarchy meant a deeper break than the establishment of dictatorship. Secondly, he underlines that the provisional government's errors were not solely responsible for the October coup, as there had been in Russia a long-standing tradition of making politics by force, not by majority decisions. Hans-Joachim Torke, "Die improvisierte Demokratie. Februar-Revolution und Provisorische Regierung in Rußland", in idem, Holm Sundhaussen: 1917-1918 als Epochengrenze(Wiesbaden, 2000), 29-56. 
[...]: No doubt, here "men made history'." 56 Of course, they could only make history, as is implied in Hildermeier's more than 300 pages, because longer-term structures and short-term processes allowed them to.

\section{Culture, periphery, nations}

There is no doubt that the historiography of Russia's 1917 produced in the 1970s overcame all the restraints mentioned in the second part of this article. The new generation of historians - the age cohort of the $1940 \mathrm{~s}^{57}$ - played a major role. Its members reached full professorships and were able to establish research that was based on sources, methods, theoretical frameworks; they communicated with their colleagues in the Soviet Union and in the West. In the German Federal Republic, more and more professorships for Eastern European History were established. A certain Cold-War effect did play a role, although minor and one among many, since the scope of research went beyond contemporary history and the history of communist Eastern Europe. The enlargement of the institutional basis certainly helped increase the quantity of young scholars working in the field of Russian history. Research became pluralistic as to approaches, topics, theoretical backgrounds, perspectives and interpretations. Step by step, the social history paradigm lost its dominant role.

One can hardly speak of a cultural "turn" in the 1980s, but there is no doubt that culture mattered more and more. Certainly, cultural studies of the Russian Revolution had already begun in the 1970s simultaneously with the studies mentioned here. The aforementioned Schramm group working on the third volume of the Handbook of Russian History indeed placed culture at the end of the chapter on 1917, but its role was not at all denied since several scholars had begun to study it. ${ }^{58}$ When in 1983 Gernot Erler summed up

56Cf. Hildermeier, Die Russische Revolution, 147-245 and 299-307, quotations, 230, 300, 299, 230, 301. In his later, significantly shorter introduction to the Russian Revolution published in Fischer Taschenbuch Verlag, Hildermeier relativized his wording: "It was certainly a downplaying statement that power was lying on the streets in the Russian October. The Bolsheviks did not pick it up, but overturned a legitimate government by military force. What is correct in this observation is what actually was meant: that it was comparatively easy to do this." Manfred Hildermeier, Die Russische Revolution (Frankfurt on the Main, 2004), 36f.

57Historians like Heiko Haumann, Stephan Merl, Manfred Hildermeier, Dietrich Beyrau, Bernd Bonwetsch, Helmut Altrichter.

58Oskar Anweiler, Karl-Heinz Ruffmann, eds., Kulturpolitik der Sowjetunion (Stuttgart, 1973); Eberhard Ködler-Bunter, Gernot Erler, eds., Kultur und Kulturpolitik in der Sowjetunion (Berlin, 1978); Nyota Thun, Das erste Jahrzehnt: Literatur und Kulturrevolution in der Sowjetunion (Berlin (East), 1973); Hubertus Gassner, Eckhart Gillen, eds., Zwischen Revolutionskunst und Sozialistischem Realismus: Dokumente und Kommentare. Kunstdebatten in der Sowjetunion von 1917 bis 1934 (Cologne, 1979); Gernot Erler, Rainer Georg Grübel, Krisztina Mänicke-Gyöngyösi, eds., Von der Revolution zum Schriftstellerkongress: Entwicklungsstrukturen und Funktionsbestimmungen der russischen Literatur und Kultur zwischen 1917 und 1934 (Veröffentlichungen der Abteilung für Slavische Sprachen und Literaturen des Osteuropa-Instituts (Slavisches Seminar) der Freien 
the results of this field in German and international research, one could not oversee the meaning and growing role of cultural studies on the Russian revolution including topics of daily life, women and abandoned children. ${ }^{59}$

Within these cultural studies, a certain tendency may be observed that did not, for that matter, reduce the existing pluralism. Historians looked at cultural and ideological alternatives to Leninist and official cultural policy. Proletkult became one of the main fields of research, and Aleksandr Bogdanov, one of the Proletkult thinkers, the theoretician of epistemology, system-theory, culture theory, whom Lenin chose as one of his most dangerous enemies in 1909-1910, was studied intensely. ${ }^{60}$ Again, the aforementioned Richard Lorenz was at the forefront, this time the cultural one, when in 1969 he edited documents on the proletarian cultural revolution. ${ }^{61}$

And there was the Anti-Lorenz. Scheibert's opus magnum Lenin in Power was published in $1984 .{ }^{62}$ The author had spent almost 20 years on the manuscript. In the end, the 700-page book evoked a slip box turned upside down, with its huge amount of partly unpublished sources - newspapers, journals from all over Soviet Russia, even rare provincial ones, private notes-mainly from American libraries. Scheibert claimed "to analyse the relationship between economic [or] social practical constraints and Lenin's or the party elite's margins of decision", ${ }^{63}$ but he became extremely frustrated by his topic, as he wrote in a letter to a colleague: "Meanwhile I doubt more and more that the plain banality of this so-called revolution actually deserves description." He painfully noticed that he had spent many years

Universität Berlin 47) (Wiesbaden, 1979); René Fülöp-Miller, Geist und Gesicht des Bolschewismus: Darstellung und Kritik des kulturellen Lebens in Sowjet-Russlands ( Zürich, 1926), was influential for these historians.

59Gernot Erler, “Den 'Neuen Menschen' vor Augen: Kultur und Lebensweise”, in Schramm, ed., Handbuch der Geschichte Russlands, Vol.3,1: Von den autokratischen Reformen zum Sowjetstaat, 759-780.

60Peter Gorsen, Eberhard Knödler-Bunte, Bion Steinborn, eds., "Proletkult. Eine Dokumentation zur Proletarischen Kulturrevolution in Russland”, Ästhetik und Kommunikation, 2 (1972): 63-203; Peter Gorsen, Eberhard Knödler-Bunte, eds., Proletkult, (Stuttgart-Bad Canstatt, 1974/1975, 2 vols.); Gabriele Gorzka, A. Bogdanov und der russische Proletkult: Theorie und Praxis einer sozialistischen Kulturrevolution (Frankfurt on the Main, 1980); Krisztina Mänicke-Gyöngyölsi, "Proletarische Wissenschaft" und "sozialistische Menschheitsreligion" als Modelle proletarischer Kultur: Zur linksbolschewistischen Revolutionstheorie A.A. Bogdanovs und A.V. Lunačarskijs (Berlin, 1982).

61Richard Lorenz, ed., Proletarische Kulturrevolution in Sowjetrussland (1917-1921): Dokumente des "Proletkult"(München, 1969).

62Peter Scheibert, Lenin an der Macht: Das russische Volk in der Revolution 1918-1922(Weinheim, 1984).

63Abel, Kunstraub, 239. 
on a topic "without being able to identify myself with any of the protagonists in one way or another". 64

His book was unique at the time. The amount of sources, his intention to focus on the fates of individuals as far as they appeared in the sources, to describe "social reality [...] as it was and not as it should be", his approach consisting in looking at "the experiences of the contemporaries" and declaring "the principles of simple humanity" as his methodological basis were not at all common at the time. He described situations in cities and in the countryside, scenes of terror and famine, disputes within committees, the work of the trade-unions and many more situations and occurrences, thus creating a colourful mosaic of loosely connected incidents and observations. One might call his book a micro-history or daily-life history of the revolution though it certainly could not satisfy either methodological purists of Alltagsgeschichte (daily-life history) and micro-history or other historians, whose majority had difficulties finding an appropriate approach at all. ${ }^{65}$

Strangely enough, the book was published by a publisher specialising in chemistry and got no applause at all. The reviews were as bizarre as the book and very German insofar as they mainly focused on questions of methods and sources, but hesitated to evaluate Scheibert's "scenes of power" (as the book should have been entitled) as the extreme dark side of the revolution. To put the finger in the physical and mental wounds of the contemporaries of the revolution and civil war was not the most appreciated approach during the - with some exaggeration - "Marxist" years of Soviet studies.

Although there is a lot to be said against Scheibert's book, it nonetheless opened two fields of research that were still to come. His book may be regarded as a precursor of the history of violence during and after the Russian revolution. ${ }^{66}$ Scheibert became the Melgunov of the 1980s.${ }^{67}$ Of course, descriptions of this specific aspect of Bolshevik power could hardly be expected from Lorenz or other leftists. Additionally, the book unintentionally helped orient research to the revolution outside the capitals.

64Ibid., 240.

65Cf. Reviews by Oskar Anweiler, in Osteuropa, 35 (1985): 859-860; Dietrich Beyrau, in Archiv für Sozialgeschichte, 27 (1987): 724-727.

66Stefan Plaggenborg, "Weltkrieg, Bürgerkrieg, Klassenkrieg: Mentalitätengeschichtliche Versuche über die Gewalt in Sowjetrußland. Ein Literaturbericht", Historische Anthropologie, 3 (1995): 493-505; idem, "Gewalt und Militanz in Sowjetrußland 1917-1930”, Jahrbücher für Geschichte Osteuropas, 44 (1996): 409-430.

67Sergei P. Melgunov, Krasnyi terror v Rossii [Red Terror in Russia] (Berlin, 1924). 
In retrospective, two remarks must be made: Firstly, Scheibert's book had an original anti-Marxist reflex directed against the mainstream historiography of the Russian revolution (as he saw it), in particular against "Red Marburg" and the "red" historians of his own group of scholars; secondly, the book was a strange rehabilitation of the Russian people by a historian who as a member of special Nazi forces once had robbed the materials he later eagerly wanted to study on behalf of "humanity".

Let us come back to the developments in historiography. Not surprisingly, studies on the Russian periphery soon appeared with Scheibert again at the forefront. ${ }^{68}$ Research in this field showed different developments, forces and constellations for turnover from those in Petrograd or Moscow. The liberal alternative became much more realistic than in the centres of the revolution. ${ }^{69}$ The "white" movement was studied in detail. ${ }^{70}$ Not surprisingly either, research discovered the uprising of nationalities. The research on 1917 and its aftermath became more and more multi-perspective; it questioned the "Russian" exclusivity of the revolution. Helmut Altrichter's monography on the revolution reserved a long chapter on the emancipation of nationalities from Russian rule. ${ }^{71}$ The author's general approach consists in a "political, social and cultural description" presenting the revolution as a "most complex context" that "resists simple attempts of explanation and can be understood only out of its time". ${ }^{72}$ In so doing, Altrichter pays special attention to the multidimensional character of preconditions, events and perceptions: from the "simultaneity of the non-simultaneous" in the late tsarist empire to the "heterogeneity of acting groups and their guiding principles", to the "tensions between centre and periphery". ${ }^{73}$

In its content, Altrichter's presentation is compatible with the principles of German-speaking historiography of 1917 as they appear in Geyer and Hildermeier, his heart beats for social history: consideration of the different "acting groups" of the revolution

68Peter Scheibert, "Saratov - Stadt und Gouvernement in Revolution und Bürgerkrieg (Oktober 1917 bis 1922)", in Alexander Fischer, Günter Moltmann, Klaus Schwabe, eds., Russland - Deutschland - Amerika: Festschrift für Fritz T. Epstein zum 80. Geburtstag (Wiesbaden, 1978), 198-211.

69Andreas Kappeler, Russland als Vielvölkerreich: Entstehung - Geschichte - Zerfall (München, 1992), 288-299; Tanja Penter, Odessa 1917: Revolution an der Peripherie (Cologne et al., 2000); Stefan Karsch, Die bolschewistische Machtergreifung im Gouvernement Voronež (1917-1919) (Stuttgart, 2006).

70Nikolaus Katzer, Die Weiße Bewegung in Russland: Herrschaftsbildung, praktische Politik und politische Programmatik im Bürgerkrieg (Cologne, et al., 1999).

71Helmut Altrichter, Russland 1917: Ein Land auf der Suche nach sich selbst (Paderborn et al., 1997).

72Ibid., 85-97, quotations, 85, 95 .

73See Altrichter's introductory remarks, 25-74. 
quickly leads to the "limits of the historical explanatory power" of the government-centred narrative. Here, Altrichter pursues a new conceptualization in the historiographical description of 1917 by looking at the different social groups of the revolution-workers, soldiers, peasants and bourgeois - in a systematic classification within a chronological framework from the end of 1916 to the end of $1917 .{ }^{74}$ The benefits of Altrichter's synthetic approach lie not least in his successful endeavour to come as close as possible to the different realities of 1917, which existed side by side and sometimes were intertwined. Of course, everything has its price: the readers pay for novel vividness with the waiver of pointed and easily memorable theses - in the overall view, 1917 was just too complex, which seems to be confirmed by Altrichter's avoidance of an all-encompassing final chapter. ${ }^{75}$

In his introduction, Altrichter raises the question whether the keys to "a new synthesis of the histories of ideas, politics and society" are to be found in the "development from social to 'cultural history', which questions previous terms, understands societal utterances and behaviour as well as language and culture as a system of discourse, and tries to decode them". ${ }^{76}$ Indeed, cultural studies conducted mostly by a new age-cohort of historians continued with various approaches and topics, some of them mainly referring not to the year 1917 , but to the time after the Bolshevik seizure of power. ${ }^{77}$ The latest monograph on the Russian Revolution, published in 2001, which turned out to be a history of the Soviet Union between 1917 and the early 1930s, could therefore rely on a solid basis of cultural studies. This becomes clear when the author talks about changes in "public space" in Petrograd or, in an Alltagsgeschichte perspective, about the kommunalka, the Soviet type of shared residence, which came into being by "redistribution of municipal living space". Likewise, the author's emphasis on "moods", "stereotypes" or representations that were decisive in the self-positioning of workers and soldiers, and recognition that the sharp opposition of Russia's lower classes to the provisional government rested just as much on certain ways of perception, indicate that cultural history concepts can, too, be used fruitfully in the study of the 1917 Revolution. The radical rejection of the "bourgeois" ministers by a growing majority of

74Cf. Altrichter, Russland 1917, 259-398.

75See Christoph Mick, "Review of: Helmut Altrichter, Rußland 1917: Ein Land auf der Suche nach sich selbst, Paderborn u.a. 1997”, Osteuropa, 49 (1999): 220-221.

76Altrichter, Russland 1917, 93.

77Karl Schlögel, Jenseits des Großen Oktober: Das Laboratorium der Moderne. Petersburg 1909-1921 (Berlin, 1988); Stefan Plaggenborg, Revolutionskultur. Menschenbilder und kulturelle Praxis in Sowjetrussland zwischen Oktoberrevolution und Stalinismus (Cologne, 1996); Benno Ennker, Die Anfänge des Leninkults in der Sowjetunion (Cologne, 1997). 
workers often had its reason less in concrete political differences than in mental hostility towards the declared "class enemy". ${ }^{78}$

The last book on the Russian revolution mentioned here indicates a certain slowdown in research in comparison to previous years. Probably there will be little contradiction when the situation nowadays is described as follows: research about 1917 has stopped being eruptive and path-breaking; the caravan of historians has pushed along to Stalinism and recently from there to post-Stalinism; the Revolution has become a subject of jubilee-publications. ${ }^{79}$ There is little hope (and little reason) for a new wave of research on 1917, there is even less hope that in 2017 the expected quantity of publications about 1917 will offer an appropriate quality of new insights. That is not a problem inherent to German historiography alone but an indicator of research normality, research conjunctures and market mechanisms. At least the latter are not known for producing fine research. Today, one can hardly identify a direction in the historiography of 1917. The question of how research on 1917 could produce new insights has nothing to do with "German" historiography any longer. The answer could be given by a comparative historical analysis of Soviet Russian developments as part of the newly erected authoritarian post-war regimes after 1917-1918, modern Turkey and fascist Italy included. ${ }^{80}$ It would help perceive phenomena and dimensions, for example, of party rule, physical violence, ideologies, law (or lack thereof), personality cult and religious policies as general problems of the period with a common basis in history and not in the peculiar societies and "national" preconditions of development alone, according to the tasks of comparative historical research originally put up by Marc Bloch. ${ }^{81}$ Questions of mental, cultural and habitual longue durée stretching from tsarist to Soviet Russia also deserve to be considered in more detail. Such an approach would have both to accept and overcome 1917 as a turning point by tracing traditions and legacies of the pre-revolutionary period in Soviet political and societal behaviour. What is to be done should be tackled by international research and discussion.

78See Dietrich Beyrau, Petrograd, 25. Oktober 1917: Die russische Revolution und der Aufstieg des Kommunismus (München, 2001).

79A recent example: Helmut Altrichter, Jörg Baberowski, Matthias Stadelmann et al., 1917 - Revolutionäres Russland (Darmstadt, 2016).

80Stefan Plaggenborg, Ordnung und Gewalt. Kemalismus - Faschismus - Sozialismus (München, 2012).

81Marc Bloch, "Pour une histoire comparée des sociétés européennes", Revue de synthèse historique, 46 (1928): $15-50$. 
University of Erlangen-Nuremberg, Department of History

matthias.stadelmann@fau.de 